\title{
Technology: mechanical ventilation strategy versus tactics
}

\author{
Tecnologia: estratégia versus táticas de ventilação mecânica
}

\author{
Jose Irazuzta* \\ Nota: a versão completa em português deste editorial está disponível em www.jped.com.br
}

\begin{abstract}
Dr. Viana et al. attempted to decipher the effects of different technique of mechanical ventilation on ventilatorinduced lung injury. They appropriately emphasize that mechanical ventilation is not just support therapy for respiratory failure but rather a component of the injuryrecovery-repair continuum process. ${ }^{1}$ We live in the era of lung protective ventilation strategies, with the use of tactics like the utilization of low tidal volumes, however some of these come with the risk of decreasing
\end{abstract} fractional residual capacity and lung derecruitment. Ventilator-induced lung injury is in great part due to a repetitive application of excessive stress or strain producing architectural distortion and inflammation on unstable areas of the lung. ${ }^{2}$ Juxtaposition of open and closed respiratory units amplifies strain at their interfaces. Atelectasis lead to a reduction in the number of junctional interfaces with each one of them having to bear a higher stress or strain. Nonappropriately recruited respiratory units undergo cyclic inspiratory opening and expiratory collapse. A lung is said to be "open" when all potential recruitable lung is aerated. In an "open lung" trans-pulmonary pressures are distributed throughout the lung decreasing the stress in comparison with the same pressures applied to a lung with closed and open units. The overall lung strain correlates with aerated volume as a fraction of aeratable capacity. ${ }^{2}$ However, recruited areas can only be kept open by applying appropriate pressure at the end of the expiratory cycle. The overriding notion is that stress or strain injury during mechanical ventilation could be decreased in proportion to the lung that participates in the distribution of air throughout the respiratory cycle. Avoiding cyclic recruitment/de-recruitment clearly decreases inflammation, however, opening atelectatic areas also prevents the release of inflammatory mediators even when tidal opening does not take place. ${ }^{3-4}$ In summary, tidal mechanical breaths should be applied to an already "open lung".

The carefully designed, well-executed study by Dr. Viana et al. was able to produce a consistent lung injury after saline lavage and endotoxine administration emulating

* MD, The Floating Hospital for Children, Tufts-New England Medical Center, Boston, MA, USA.
ARDS in the clinical scenario. ${ }^{1}$ The decrease in compliance and oxygenation gives the reader a sense for the severity of the lung injury before randomization. The animals underwent a period of stabilization and were appropriately randomized. Because oxygenation is the product of matching ventilation/ perfusion, and this last requires fractional residual capacity, alveolar recruitment can be correlated to changes in $\mathrm{PaO}_{2}$ in this experimental setting.

Surfactant, high frequency ventilation and liquid ventilation strategies were able to bring oxygenation within the realm of clinical goals. Four hours later the authors quantify differences in lung damage by appropriate histological and biochemical methods. They carefully attempted to elucidate disparity in lesion severity between dependent and non-dependent areas, an injury that may become more pronounced with a longer experiment.

It's not so long since high-frequency ventilation was labeled as experimental or non-conventional mechanical ventilation. I doubt that we can apply the same terms taking into account the present widespread utilization of this modality. As we gain understanding of technologies we line toward a pragmatic approach to their utilization, overriding the notion of conventional or non-conventional methods. This article leads us to compare technologies regardless of present clinical feasibility and solely on the merits of the techniques. High frequency ventilation is viewed as the epitome for a low-stretch, high-recruitment strategy. When high frequency is applied with the "open lung" concept, which often translates into an initial application of recruitment maneuvers, it provides oxygenation and ventilation while minimizing ventilator-induced lung injury. Partial liquid ventilation is an intriguing technique, where a liquid air interface forces us to conceptualize a different physical dynamic. Liquid ventilation seems to have the ability to rapidly stabilize lung units with different time constants therefore rapidly establishing an "open lung" strategy. It has other theoretical advantages including attenuation of the lung inflammatory cascade, even when this is triggered by a remote organ injury. High frequency ventilation and liquid ventilation were able to reduce the inflammation and histological scores. I suspect that these differences may have become more evident if this experiment could have been prolonged in time. Dr. Viana et al. found that liquid 
ventilation may have had a protective effect in the dependent areas, which is an intriguing result that merits further study. However, the superiority of liquid ventilation over conventional treatments has yet to be demonstrated and long-term safety in regard to the effects of perfluorocarbons on the immune system remains an important obstacle. The introduction of surfactant to clinical practice has made a significant impact on the treatment of hyaline membrane disease. However, the cost of this therapy when applied to ARDS, which seems to be only associated with a brief reduction in ventilator dependency, precludes its widespread application. Regardless, surfactant administration initiates a dynamic process where compliance rapidly changes, in the hours following its application, requiring frequent ventilator adjustments. As the authors appropriately pointed out, the dynamic improvement in compliance may have created cyclic distention in dependent areas due to the lack of adjustment of the positive end expiratory pressure (PEEP). The experimental scenario created by $\mathrm{Dr}$. Viana et al. teaches us that we cannot underestimate the importance of applying the appropriate amount of PEEP to maintain alveolar recruitment. When PEEP succeeds in keeping open otherwise unstable units, it diminishes lung heterogeneity and decreases stress injury. However, the application of PEEP to a rapidly changing lung, due to surfactant administration, requires frequent adjustments. To maintain the strategy of keeping the lung open, tactics need to change e.g. initial recruitment maneuvers are followed by adjustments of PEEP as compliance change.
Nevertheless, even though there was a placebo and control group pitched against three treatment groups, I concur that this experiment was a " 2 horse race" as recently labeled by Kavanagh. ${ }^{5}$ Recruited versus non-recruited lung strategy is the final comparison, rather than a particular technique of mechanical ventilation. The different technologies are tools or tactics that are subordinated to a strategy. It is important to keep the lung recruited during the ventilatory cycle regardless of the technique. This last could be obtained with high frequency ventilation, liquid ventilation or adequate use of PEEP.

\section{References}

1. Viana MEG, Sargentelli GA, Arruda ALM, Wiryawan B, Rotta AT. O impacto de estratégias de ventilação mecânica que minimizam o atelectrauma em um modelo experimental de lesão pulmonar aguda. J Pediatr (Rio J). 2004;80:189-96.

2. Marini JJ, Gattinoni L. Ventilatory management of acute respiratory distress syndrome: a consensus of two. Crit Care Med. 2004;32:250-5.

3. Chu EK, Whitehead T, Slutsky SA. Effects of cyclic opening and closing at low- and high-volume ventilation on bronchoalveolar lavage cytokines. Crit Care Med. 2004;32:168-74.

4. Kisala JM, Ayala A, Stephan RN, Chaudry IH. A model of pulmonary atelectasis in rats: activation of alveolar macrophage and cytokine release. Am J Physiol. 1993;264:610-14.

5. Kavanagh BP. ARDS: ventilation with $6-8 \mathrm{ml} / \mathrm{kg}$ is a standard for all? In: Current Concepts in Pediatric Critical Care Course. Shanley TP, editor. Des Plaines, IL: Society of Critical Care Medicine; 2004. p. 137-144.

\title{
Esofagite de refluxo em lactentes: conhecimentos atuais e as lacunas do conhecimento
}

\author{
Reflux esophagitis in infants: current knowledge and future challenges
}

Elisa de Carvalho' ${ }^{1}$ Ana Aurélia R. Silva², Ana Raquel M. Franco ${ }^{3}$

\footnotetext{
Os processos patológicos do esôfago na faixa etária pediátrica foram pouco estudados e valorizados até recentemente, quando a evolução dos métodos diagnósticos,

1. Mestre em Ciências da Saúde pela Universidade de Brasília.Coordenadora da residência médica em Gastroenterologia Pediátrica, Hospital de Base do Distrito Federal. Professora, Faculdade de Medicina, Escola Superior de Ciências da Saúde (Secretaria de Saúde do DF). Presidente do Departamento de Gastroenterologia Pediátrica da SP-DF. Especialista em Pediatria pela SBP e AMB e Especialista em Gastroenterologia Pediátrica pela SBP, FBG e AMB.

2. Médica pediatra, Setor de Gastroenterologia Pediátrica, Hospital de Base do Distrito Federal.

3. Mestre em Ciências da Saúde pela Universidade de Brasília. Médica pediatra, Setor de Gastroenterologia Pediátrica, Hospital de Base do Distrito Federal.
}

como a endoscopia digestiva alta (EDA), permitiu o avanço dos conhecimentos. Atualmente, sabemos que a alergia ao leite de vaca, as dismotilidades, algumas infecções, traumas, substâncias cáusticas e o refluxo gastroesofágico (RGE) podem ocasionar enfermidades esofágicas (conhecimentos atuais). Entretanto, alguns aspectos importantes ainda não estão estabelecidos, como o significado e a evolução da esofagite histológica no lactente (lacunas do conhecimento), dados abordados na excelente pesquisa publicada por Vieira et al. ${ }^{1}$.

Os autores ${ }^{1}$, referência nacional para temas relacionados a EDA em pediatria, analisaram a presença ou ausência de esofagite de refluxo (ER) por meio da comparação entre 